\title{
Legal Obstacles to Private Enforcement of Competition Law $^{*}$
}

\author{
Michal S. Gal and Rivi Dahan**
}

\begin{abstract}
Private enforcement of competition law serves many important goals, including deterrence of future anti-competitive harms and correction of past harms. This article sheds light on several potential legal obstacles to such enforcement which could prevent it from achieving its goals. The examples mainly build upon the experience of different jurisdictions with private litigation. It also suggests some possible solutions for dealing with or limiting such obstacles. As Europe is in the early stages of applying its Damages Directive and creating a private competition law enforcement regime, recognising - and possibly avoiding - obstacles to efficient private enforcement is both timely and important.
\end{abstract}

KEYWORDS: Competition Law, Private Enforcement, Decision Theory, Damages Directive

\section{Introduction: Private Enforcement - An Important Step Forward} Private enforcement of competition law serves many important goals. It increases deterrence. ${ }^{1}$ Effective deterrence requires that the expected penalty, which is a function of both probability of detection and punishment

* DOI: https://doi.org/10.7559/mclawreview.2019.1835.

** Professor and Director of the Centre for Law and Technology, University of Haifa Faculty of Law, and President, International Association of Competition Law Scholars (ASCOLA); Lawyer, LL.M.

${ }^{1}$ For some empirical works on the subject focusing on the U.S., see Robert H. Lande and Joshua P. Davis, "Comparative deterrence from private enforcement and criminal enforcement of the U.S. antitrust laws", Brigham Young University Law Review 2011, 2 (2011): 315; Robert H. Lande and Joshua P. Davis, "Restoring the legitimacy of private antitrust enforcement", in A Report to the 45th President of the United States (American Antitrust Institute's Transition Report on Competition Policy), 219. 
as well as the size of the penalties imposed, exceeds the expected gains of competition law infringements. By increasing both parameters, private enforcement reduces the profitability of engaging in anti-competitive conduct. In addition, private suits compensate those harmed by the infringements, thereby furthering corrective justice. ${ }^{2}$ Finally, by increasing incentives of market players to identify violations, private enforcement may strengthen awareness and support for competition laws and their enforcement, thereby contributing to the culture of competition. ${ }^{3}$ Accordingly, the importance of private litigation of competition law violations cannot be overstated. ${ }^{4}$

If structured efficiently, a positive interplay may be created between private and public enforcement. Most commentators point to the fact that public enforcement may facilitate private enforcement because of followon actions for damages, which can be based on the gathering of information and proof of the violation by the public authority, making it easier for the private plaintiff to concentrate on proving specific damages. ${ }^{5}$ Moreover, public enforcement contributes to public awareness of competition law prohibitions, which can lead to more private cases. Private enforcement affects public enforcement as well. On the one hand, private enforcement might duplicate enforcement efforts and costs and affect the willingness of regulators to impose high penalties in public enforcement cases. ${ }^{6}$ It might also affect the development of legal doctrines to reflect private interests rather than public ones, given that courts might not always be aware of the wider implications of their findings. Also, private competition law enforcement might negatively impact leniency. Whereas infringers can potentially be granted immunity from public enforcement or reduction of fines if they cooperate with the authorities, leniency does not extend

\footnotetext{
${ }^{2}$ Wouter P. J. Wils, "The relationship between public antitrust enforcement and private actions for damages", World Competition 32 (2009): 3.

${ }^{3}$ Maarten Pieter Schinkel and Jakob Rüggeberg, "Consolidating antitrust damages in Europe: A proposal for standing in line with efficient private enforcement", World Competition 29, no. 3 (2006): 396.

${ }^{4}$ For recognition of its importance see, e.g., Judgment of 20 September 2001, Courage Ltd. v. Bernard Crehan, C-453/99, EU:C:2001:465, paragraphs 26-27. The U.S. Supreme Court recently acknowledged it as well: Apple Inc. v. Pepper et al., 17-204, 587 U.S. (2019), 12, 14 ("Leaving consumers at the mercy of monopolistic retailers [...] directly contradict[s] the longstanding goal of effective private enforcement and consumer protection in antitrust cases").

${ }^{5}$ Wils, "The relationship", 19-20.

${ }^{6}$ Wils, "The relationship".
} 
to private suits. ${ }^{7}$ On the other hand, private enforcement can strengthen calls for public enforcement of competition laws, due to cost savings to plaintiffs created by follow-on actions. This, in turn, may directly or indirectly reduce inefficient enforcement or political capture of competition authorities. Furthermore, by bringing more cases to trial, private cases may increase deterrence and thus save public resources and may also clarify and develop competition law. ${ }^{8}$

Commentators point to several advantages private litigants may bring to the table. First, those harmed might have strong incentives to pursue an end to an anti-competitive conduct in order to stop it from harming them and to receive compensation for damages. ${ }^{9}$ Furthermore, by enabling the harmed party to take the lead in the legal process, private suits might potentially add a psychological dimension to the pursuit of violations, possibly uncovering otherwise unknown infringements. While public authorities may also have strong incentives to put an end to such anticompetitive conduct, they may have limited funds or other priorities (such as pursuing only cases beyond a certain size of damages). Additionally, the harmed parties might be in a better position to analyse and detect an infringement. ${ }^{10}$ Market participants who possess industry-specific knowledge and interact with suppliers or rivals that behave anti-competitively are often the first to notice an infringement. They may also have access to specific evidence. ${ }^{11}$ As Brodley suggests, they are "ideal litigants in terms of litigation capability because they are likely to have the skill, knowledge of the industry, and motivation to mount a powerful case with speed and precision". ${ }^{12}$

These benefits translate into higher deterrence, especially where private suits are not simply follow-ons, which are based on prior government action and investigation. Yet, even when such cases do constitute followon suits, they still increase deterrence by increasing sanctions. Indeed, one study showed that in the sixty largest private cartel cases in the U.S. in which an infringement was found, compensation in the amount of approximately 33 billion U.S. dollars was imposed, whereas the fines imposed by

\footnotetext{
${ }^{7}$ Wils, "The relationship", 27-32.

${ }^{8}$ See. e.g., Wils, "The relationship".

${ }^{9}$ Schinkel and Rüggeberg, "Consolidating antitrust damages", 395-420.

${ }^{10}$ Schinkel and Rüggeberg, "Consolidating antitrust damages".

${ }^{11}$ Schinkel and Rüggeberg, "Consolidating antitrust damages".

${ }^{12}$ Joseph F. Brodley, "Antitrust standing in private merger cases: Reconciling private incentives and public enforcement goals”, Michigan Law Review 94, no. 1 (1995): 34.
} 
the Department of Justice in those cases stood at approximately 11.7 billion. ${ }^{13}$ Accordingly, private litigation can create a credible threat of penalties which might significantly affect the balance of expected costs and benefits of potential infringers.

Given the many advantages brought about by private competition law enforcement, it is important to develop efficient mechanisms for their enforcement. This short essay briefly surveys some legal pitfalls to be avoided, which are based on the experience of jurisdictions in which private actions were already employed. The essay is not intended to provide a complete list of challenges but rather attempts to shed light on several pitfalls that can completely change the dynamics of private enforcement in a way that harms social welfare. Given that private enforcement in the EU is still in its early stages, the time is ripe for such a discussion.

\section{Contractual Limitations on the Right to Private Actions}

An important issue involves the legality of contractual limitations that market players place on the ability or incentives of consumers or suppliers to bring private actions. Such contractual limitations can take many forms. They can be direct, for example by mandating the parties to waive their rights to challenge certain conduct. ${ }^{14}$ They can be indirect, for example by imposing a mandatory contractual requirement that any claims be settled through a personal arbitration process, that actions only be brought in a pre-specified court or country, that class actions be not allowed, or that the contract be automatically terminated once a private action is brought. While some of these limitations may have pro-competitive justifications, they may significantly affect the incentives and the ability of those harmed by anti-competitive conduct to bring private actions. Furthermore, if they are included in boilerplate contracts of dominant firms, their contractual partners might not easily avoid them. ${ }^{15}$

\footnotetext{
${ }^{13}$ Joshua P. Davis and Robert H. Lande, "Toward an empirical and theoretical assessment of private antitrust enforcement", Seattle University Law Review 36, no. 3 (2013): 1296-1333; Waller Spencer Weber, "Towards a constructive public-private partnership to enforce competition law", World Competition 29, no. 3 (2006): 367.

${ }^{14}$ See. e.g., the discussion of the anti-competitive effects of no-contest clauses in patent licensing agreements, which have many parallels to this case: Michal Gal and Alan D. Miller, "Patent challenge clauses: A new antitrust offense?", Iowa Law Review 102, no. 4 (2016): 1477; Alan D. Miller and Michal Gal, "Licensee patent challenges", Yale Journal on Regulation 32, no. 1 (2015): 121.

${ }^{15}$ Albert H. Choi and Kathryn Spier, "Class actions and private antitrust litigation", Virginia Law and Economics Research Paper 29, no. 1 (2019): 2.
} 
In some cases, contractual limitations can completely eliminate the possibility that private actions will be brought. This may be the case when consumers are contractually prohibited from bringing class actions and the damage to each consumer is not large. In such cases, no consumer will have an economic incentive to bring a suit, a situation which economists call rational apathy. The same can be achieved by any contractual requirement that imposes extra costs on contractual parties wishing to engage in private litigation, as long as these costs are sufficiently high to counteract the expected private benefits from litigating the case.

This is not just a theoretical claim. Choi and Spier have found that actual decline in class actions in the U.S. in recent years can be partly explained by the acceptance of such contractual limitations by courts. ${ }^{16}$ As they observe, "in a series of landmark rulings (...) the U.S. Supreme Court upheld private contracts that block class actions". ${ }^{17}$ They point, in particular, to three relatively recent cases in which the Court upheld mandatory individual arbitration clauses that prevented plaintiffs from bringing class actions. Concepcion ${ }^{18}$ involved a mandatory individual arbitration clause included in a commercial contract for telephone services provided by AT\&T Mobility, a strong market player. The Court gave much weight to the Federal Arbitration Act, declaring that "courts must place arbitration agreements on an equal footing with other contracts and enforce them according to their terms" ${ }^{19}$ Epic Systems Corp. v. Lewis ${ }^{20}$ enforced mandatory individual clauses in an employment contract, even though employees often have weaker bargaining power when signing such contracts.

The third case, Italian Colors, ${ }^{21}$ involved a competition law claim. Justice Kagan, who wrote the dissenting opinion, presented the facts as follows: "The owner of a small restaurant (Italian Colors) thinks that American Express (Amex) has used its monopoly power to force merchants to accept a form contract violating the antitrust laws. The restaurateur wants to challenge the allegedly unlawful provision (imposing a tying arrangement), but the same contract's arbitration clause prevents him from doing so. That term imposes a variety of procedural bars that would make pursuit

\footnotetext{
${ }^{16}$ Choi and Spier, "Class actions".

${ }^{17}$ Choi and Spier, "Class actions".

${ }^{18}$ AT\&T Mobility LLC v. Concepcion, 563 U.S. 333 (2011).

${ }^{19}$ Ibid.

${ }^{20}$ Epic Systems Corp. v. Lewis, 138 S. Ct. 1612 (2018).

${ }^{21}$ American Express Co. v. Italian Colors Rest., 133 S. Ct. 2304 (2013).
} 
of the antitrust claim a fool's errand. So if the arbitration clause is enforceable, Amex has insulated itself from antitrust liability - even if it has in fact violated the law. The monopolist gets to use its monopoly power to insist on a contract effectively depriving its victims of all legal recourse". ${ }^{22}$ The Minority thus argued that allowing such contractual clauses to exist amounts to a "betrayal (...) of antitrust laws," given that it "confers immunity from potential meritorious (...) claims". ${ }^{23}$ Such immunity need not be an outright prohibition on bringing cases but may involve clauses that prevent the effective vindication of a competition law right. The majority rejected the claim based on the argument that "the fact that it can be more expensive to litigate individual arbitrations than they are worth does not negate the right to pursue a statutory remedy". ${ }^{24}$

Deference to arbitration clauses was also recently exhibited by the U.S. Congress. In 2017, the Consumer Financial Protection Bureau, an agency which is in charge of overseeing and regulating consumer financial contracts, sought to protect class actions in consumer financial contracts that are often boilerplate contracts. To do so, it issued a rule that prohibited mandatory arbitration clauses in certain consumer financial contracts. ${ }^{25}$ The U.S. Congress overturned the rule by a close vote. ${ }^{26}$

In our view, this is the wrong road to take. Contractual terms that practically prevent the ability of private plaintiffs to pursue a competition law claim should be prohibited. Such terms close an important door for incentivising strong market players not to engage in violations involving small individual damages but causing large aggregate harm, leaving those harmed to rely on public enforcement. They also completely shut the door on compensation for harm.

For similar reasons, courts should carefully consider before placing restrictions on the standing rights of plaintiffs. In several decisions the U.S. Supreme Court adopted positions that restrict the ability of some plaintiffs to bring class actions, basing class certification on the extent of the connection between the plaintiffs, the violation, and the damage the plaintiffs sustained. Such restraints might be justified. For example, they might limit duplication of enforcement and compensation and might

\footnotetext{
${ }^{22}$ Ibid.

${ }^{23}$ Ibid.

${ }^{24}$ Ibid.

${ }^{25}$ Choi and Spier, "Class action", 2-3, footnote 5.

${ }^{26}$ Choi and Spier, "Class action”, 2-3, footnote 5, citing to U.S. H.J. Res. 111 (October 24, 2017).
} 
prevent the misuse of private rights of action. ${ }^{27}$ Yet, it is important to balance these concerns with the benefits private enforcement brings about to ensure they are not given too much weight and that less-restrictive methods for overcoming such limitations are not overlooked..$^{28}$

We argue that competition authorities have an important role to play in the process of shaping the rules to reach an optimal balance between the competing considerations in the cases explored above. ${ }^{29}$ As noted elsewhere, competition authorities offer two main comparative advantages. ${ }^{30}$ First, they possess significant expertise and experience in analysing the competitive impact of a wide range of market conducts. ${ }^{31}$ Second, they are often less susceptible to political pressures than legislators and regulators ${ }^{32}$ due, in part, to the fact that competition law is not sector-specific and they are independent regulatory agencies. This is not to say that competition authorities are shielded from political pressures, but they are often less likely to yield to them. ${ }^{33}$ Their advisory role can take shape through submissions to relevant courts and through consultations with decision-makers on legislative and regulatory procedures that may significantly impact competition law enforcement. If made public, these actions may also create a basis for public debate. Such debate will limit the incentives and ability of decision-makers to make decisions against the public interest. ${ }^{34}$

\footnotetext{
${ }^{27}$ Choi and Spier, "Class action", 4.

${ }^{28}$ Waller, "Constructive public-private partnership"; R. Preston McAfee, Hugo M. Mialon, and Sue H. Mialon, "Private v. public antitrust enforcement: A strategic analysis", Journal of Public Economics 92, no. 10-11 (2008): 1863; Choi and Spier, "Class actions", showing that no private enforcement at all can be bad for society, yet its overuse could be bad not only for companies but mainly for consumers themselves.

${ }^{29}$ For the advisory role of competition authorities see, e.g., OECD, Relationship between Regulators and Competition Authorities (1999). For an overview of the literature on how the characteristics of regulators affect their ability to serve the public interest see, e.g., Anna Butenko, and Pierre Larouche, "Regulation for innovativeness or regulation of innovation?", Law, Innovation and Technology 7, no. 1 (2015): 52.

${ }^{30}$ Michal Gal, "3D challenges: Ensuring competition and innovation in 3D printing", forthcoming, Vanderbilt Journal of Law and Technology (2020).

${ }^{31}$ OECD, id., at 8-9.

${ }^{32}$ Harold Demsetz, The Economics of The Business Firms: Seven Critical Commentaries (Cambridge: Cambridge University Press, 1995).

${ }^{33}$ Michal Gal and Inbal Faibish-Wassmer, "Six principles for limiting government-facilitated restraints on competition", Common Market Law Review 44, no. 1 (2007): 69.

${ }^{34}$ International Competition Network, Advocacy and Competition Policy - Report prepared by the Advocacy Working Group, i-iii, 2002.
} 


\section{Excessive Pricing Litigation: The Next Tsunami?}

Private competition law actions encompass all competition law offenses that might create damages. Nonetheless, some offenses raise higher challenges to private enforcement. Nowhere are such challenges more pronounced than in private litigation of excessive pricing claims. As Gal elaborates elsewhere, private litigation of such cases might actually harm social welfare, rather than increase it, and might even clash with some notions of fairness. ${ }^{35}$ Here we present the bare bones of the argument.

Excessive pricing has long been prohibited under the "unfair trade conditions" prohibition in Article 102 of the TFEU. ${ }^{36}$ Indeed, its doctrinal roots run deep. ${ }^{37}$ Yet, for several combined reasons, it raises great difficulties for private enforcement.

The prohibition suffers from serious and inherent difficulties in its implementation. ${ }^{38}$ In particular, it lacks clear and workable criteria. The pragmatic difficulties of determining when a price becomes unfair were recognised by the Commission and by AG Wahl, who recently emphasised the "absence of a ubiquitous test and (...) the limitations inherent in all existing methods" 39 of determining when a price is excessive. He also recognised that "[b]ecause of those limitations, antitrust authorities and economists generally agree that the exercise consisting of determining the benchmark price in a case of possible excessive pricing carries a high risk of producing [errors]". ${ }^{40}$ These uncertainties come at a high cost,

\footnotetext{
${ }^{35}$ Michal Gal, "The case for limiting private litigation of excessive pricing cases", forthcoming, Journal of Competition Law and Economics (2020).

${ }^{36}$ This possibility was first acknowledged in Judgment of 29 February 1968, Parke, Davis and CO. v. Probel, Reese, Beintema-Interpharm and Centrafarm, 24/67 EU:C:1968:11. The ECJ indicated that wide variation in prices not justified on objective grounds would be a factor in determining whether conduct was abusive. This possibility was more clearly established in Judgment of 18 February 1971, Sirena S.r.l. v. Eda S.r.l. and others, 40/70, EU:C:1971:18, and most recently in Judgement of 14 September 2017, Autortiesību un komunicēšanās konsultāciju aǵentūra / Latvijas Autoru apvienība v. Konkurences padome, C-177/16 EU:C:2017:689, supra note 6, paragraph 35.

${ }^{37}$ Michal Gal, "Abuse of dominance - exploitative abuses", in Handbook on European Competition Law, ed. Ioannis Lianos and Damien Geradin (Cheltenham, UK; Northampton, MA, USA: Edward Elgar, 2013), 385.

${ }^{38}$ OECD, Roundtable on Excessive Pricing, DAF/COMP 2011 (2011).

${ }^{39}$ Opinion of AG Wahl delivered on 6 April 2017, Biedrïba "Autortiesību un komunicēšanās konsultāciju aǵentūra - Latvijas Autoru apvienïba" v. Konkurences padome, C-177/16, EU:C:2017:286.

${ }^{40}$ Opinion of AG Wahl delivered on 6 April 2017, Biedrība "Autortiesību un komunicēšanās konsultāciju aǵentūra - Latvijas Autoru apvienība" v. Konkurences padome, C-177/16, EU:C:2017:286, paragraph 42.
} 
as they might chill dynamic and productive efficiency by reducing investment incentives of those contemplating whether to invest in creating new or better products or production processes in order to enter or expand in the market. They have led the Commission to be cautious in applying the offense. An overview of the Commission's practice reveals that allegations of excessive pricing are rare. ${ }^{41}$ This state of affairs has existed ever since the excessive pricing offense was recognised.

Private litigation creates additional challenges to applying the prohibition. It prevents the use of public discretion in sorting out ex ante those cases that harm consumer welfare from those that do not. So far, competition authorities have dealt with the inherent limitations of the prohibition by adopting a cautionary and largely non-interventionist approach..$^{42}$ The option of applying public discretion in bringing excessive pricing cases, to ensure that they further welfare, is no longer available, as courts must hear all cases that come before them. Second, private suits differ significantly in what the decision-maker is required to decide, as regards the cases heard so far. Indeed, the task faced by general courts is more difficult. Up until now, competition authorities and the reviewing courts only had to determine whether a specific price set by the dominant firm was fair. In a private excessive pricing suit, this is no longer sufficient. Rather, to determine the size of damages, the court would need to identify the precise point at which the price becomes unfair. Broad-brush estimations with wide margins to avoid error are no longer possible. Yet, there is no clear methodology for determining when exactly a price becomes unfair. In the famous General Motors (GM) case, for instance, GM charged a fee that was 2,400 percent higher than the fee charged for such certificates for cars sold by GM itself. This difference is clearly excessive, and thus the decision was an easy one to make. But at what point exactly does the price start to be excessive? This is a question that the European Court of Justice (ECJ) did not need to answer, but general courts will. The combination of the above factors, together with the inherent difficulty of determining when a price

\footnotetext{
${ }^{41}$ Erik Pijnacker Hordijk, "Excessive pricing under EC competition law: An update in light of Dutch developments", in International Antitrust Law and Policy, ed. Barry Hawk (New York: Juris Publishing, 2001), 463.

${ }^{42}$ See, for example, European Commission (1975), Fifth Report on Competition Policy, point 3 ("measures to halt the abuse of dominant positions cannot be converted into systematic monitoring of prices"); European Commission (1994), XXIVth Report of on Competition Policy, point 207; and European Commission (1997), XXVIIth Report on Competition Policy, point 77; OECD, op. cit. supra note 17 , contribution of the EU, pp. 317, 321.
} 
becomes unfair, may increase overdeterrence, unless the conditions for the prohibition are set at a socially efficient level.

General courts may face further difficulties in regulating prices to ensure that dynamic efficiency is not impaired to the extent that overall welfare is harmed. ${ }^{43}$ Designing and applying a welfare-enhancing rule against excessive prices requires the decision-maker to engage in complex economic analysis and to have a sound understanding of how markets work. The courts' general lack of economic training, coupled with the vagueness of the prohibition and the need to precisely pinpoint the fair price, may lead to several "traps" that increase the risk that courts will reach socially harmful decisions. Most importantly, general courts might fall into a "fairness trap". The fact that linguistically the prohibition is based on fairness could lead some courts to disregard dynamic efficiency concerns - or, for that matter, any economic concern - and simply apply the prohibition based on moral notions of fairness. The fact that the ECJ has never explicitly endorsed the dynamic efficiency consideration strengthens this concern. ${ }^{44}$ General courts might also fall into a "cost trap": assuming that the competitive price - which is much more easily calculated - or any price near it is the fair price. Applying such a rule makes the decision-maker's job much easier and at first glance also appears to serve consumer welfare: are low, competitive prices not the very essence of competition? Furthermore, such a rule may sit well with a populist but ill-founded sentiment that firms should not be allowed to charge supra-competitive prices. Yet, it clearly harms dynamic efficiency. Other institutional limitations abound.

The factors discussed above may lead to a tsunami of excessive pricing cases, which may detract from public welfare. Indeed, in Israel, which has copied Article 102 of the TFEU into its laws ${ }^{45}$ and has recognised a private right of action and the right to bring class actions, private excessive pricing suits have become the main competition law prohibition to be litigated. While the Israeli Competition Authority has never been able to find even one excessive pricing case that would further social welfare, there has been a surge of private suits. ${ }^{46}$ In the past three years alone, almost thirty

\footnotetext{
${ }^{43} \mathrm{Gal}$, "Limiting private litigation".

${ }^{44}$ The ECJ's requirement that the cost-price ratio be significant and persistent may be an indirect indicator of such a consideration.

${ }^{45}$ Section 29A of the Israeli Competition Law 1988.

${ }^{46}$ For a survey of some of these cases, see Yossi Spiegel, "Antitrust enforcement of the prohibition of excessive pricing - the Israeli experience", in Excessive Prices and Competition Law Enforcement, ed. Frédéric Jenny and Yannis Katsoulacos (Cham: Springer International Publishing, 2018), 127.
} 
such cases were brought, pertaining to a wide range of products and services, including margarine, cottage cheese, Gillette razors, popcorn sold in cinemas, hard cheese, cocoa powder, instant coffee, cornflakes, sour cream, green tea, and Coca-Cola. As can be seen, these are very specific and not necessarily highly important - markets. None are protected from competition by high legal or regulatory barriers, none are natural or statutory monopolies, and all compete with other products. Furthermore, the price margins in some of these markets are not notably high, and in most markets the supracompetitive price arises from the comparative advantages of a more desirable product. As a result, Israeli courts have become a special kind of price regulator - one that does not have the discretion to choose the products to be regulated, lacks economic expertise, and must determine fair prices ex post. A similar danger may arise in the EU, especially in those Member States that will endorse class action. ${ }^{47}$

To overcome at least some of these concerns, it is important to place significant limitations on the ability of plaintiffs to bring private excessive pricing suits, in line with the current practice of the Commission and the numerous proposals by commentators. A combined effort by the Commission, national competition authorities, and European courts could build on and complement their comparative competences. First, the Commission and national competition authorities, potentially together with legislators, could create more detailed guidelines that reduce at least some of the vagueness in the excessive pricing prohibition. Such guidelines should emphasise, inter alia, the need to apply and differentiate both prongs of the legal test (i.e., the excessiveness and unfairness of the price charged by the dominant firm); the need to apply the rule with an eye toward a balanced view of consumer welfare (focusing not only on static efficiency but also on dynamic efficiency); and the fact that the competitive or near-competitive price must not be used as the benchmark for a fair price. The guidelines should also include a general requirement for courts to ensure that hearing the case indeed serves the public interest. Such guidelines - especially when mandatory - are especially important to counter populist and ill-founded public perceptions on what should constitute a fair price and the role of courts in regulating such prices. ${ }^{48}$

\footnotetext{
${ }^{47} \mathrm{Gal}$, "Limiting private litigation".

${ }^{48} \mathrm{Gal}$, "Limiting private litigation".
} 


\section{Fragmentation of Cases}

Fragmentation of cases may be suboptimal for defendants, plaintiffs, and courts. Let us assume that a cartel negatively affects consumers all over the $\mathrm{EU}$, and numerous parallel private damages actions are brought in different Member States, or even in different courts within the same State. Let us also assume that the outcome in each court hearing the case would have been similar, that is, the court would have found that the cartel existed and consumers had been harmed and would have calculated the harm in a similar fashion. This leads to duplication of financial costs as well as of time and effort. Put differently, under the current system, many resources will be wasted on cases where plaintiffs and defendants are jockeying in literally dozens of cases involving the same basic claims against the same set of defendants. ${ }^{49}$ Furthermore, fragmentation might limit incentives of the plaintiffs to bring the case in the first place. This is especially relevant where class actions are allowed: the lower the overall compensation (due, inter alia, to the size of the class), the lower the expected compensation, and the lower the economic motivation to bringing the case or to invest in proving all of its effects, potentially only dealing with the low-hanging fruits.

Fragmentation of cases might also prevent otherwise good settlements for consumers due to externalities among parallel cases. In accordance with game theory, even if the defendant had otherwise agreed to settle for a certain amount in the first case, he might not have done so if he had assumed that the first settlement will serve as a signal for other courts or as a baseline for the next settlement. ${ }^{50}$ So instead of entering into it, the defendant could choose to fight harder than otherwise optimal for him and for the plaintiffs in the first court. The same phenomenon is observed in other areas with similar institutional arrangements, such as securities litigation. Accordingly, parallel cases might prevent compensation and limit deterrence. Finally, fragmentation limits the ability of the decisionmaker to look at the bigger picture, which might be necessary in order to offer a better allocation of damages among all harmed, to ensure that all are compensated fairly and that defendants bear less of a risk of duplicative compensation. ${ }^{51}$

\footnotetext{
${ }^{49}$ Schinkel and Rüggeberg, "Consolidating antitrust damages".

${ }^{50}$ Schinkel and Rüggeberg, "Consolidating antitrust damages".

${ }^{51}$ Schinkel and Rüggeberg, "Consolidating antitrust damages".
} 
In light of the above, courts should be more lenient with requests to consolidate cases. They should also not disregard similar private actions in other courts or sequencing issues, should the relevant information be presented to them. Article 15 of the Damages Directive relates to "actions for damages by claimants from different levels in the supply chain", which can "lead to a multiple liability or to an absence of liability of the infringer". In such cases, national courts may "take due account of (a) actions for damages that are related to the same infringement of competition law, but that are brought by claimants from other levels in the supply chain; (b) judgments resulting from actions for damages as referred to in point (a)". A similar logic can and should be carried over to parallel claims in national courts, even at a similar level of the supply chain or in different Member States.

Institutional solutions might also be contemplated. Schinkel and Rüggeberg suggest that the assessment of damages in a specific case be entrusted in the hands of a "central authority". This public unit will act as an amicus curiae and will have the resources and ability to perform an investigation of the total economic damage caused by the infringement as well as the portion of the damage in the specific case. The court will not be obligated to adopt the assessment, but it could reduce some of the obstacles to proving competition law offenses and reduce duplication of costs. The proposal is designed to ensure that private action provides efficient and proper compensation and is not disproportional from any perspective. ${ }^{52}$

Finally, in line with a proposal made by Gal elsewhere, ${ }^{53}$ in light of the problem of sub-optimal deterrence of cartels arising from the existing atomistic system of competition enforcement, it might be worth considering the adoption of legal tools which enable courts to adopt and rely upon findings of hard-core cartels in other courts, provided that such cartel decisions meet criteria that ensure that such reliance is reasonable and fair. This "free movement of judgments" holds potential to overcome the main obstacles to efficient deterrence and to significantly increase both domestic as well as global welfare. Its costs can also be largely overcome by designing appropriate solutions. The political implications are also not prohibitive. Indeed, jurisdictions already rely on judgments of other courts that

\footnotetext{
${ }^{52}$ Schinkel and Rüggeberg, "Consolidating antitrust damages".

${ }^{53}$ Michal Gal, "Free movement of judgments: Increasing deterrence of international cartels through jurisdictional reliance”, Virginia Journal of International Law 51, no. 1 (2010): 57.
} 
do not significantly differ from the decisions at hand.${ }^{54}$ Although the proposal was made with regard to international collateral estoppel, its logic can be applied even more easily to cases that only involve courts in EU Member States.

\section{Calculating the Height of Damages}

One of the major difficulties involved in private competition law litigation involves the calculation of damages caused by the infringement. While competition authorities impose fines based on firms' turnover - which does not require them to engage in an analysis of the exact harms created by the competition law offense - courts cannot take a similar path. They must engage in fact-based economic analysis of the effects of the conduct on plaintiffs.

Calculating such damages might raise significant difficulties. Below we note some of them. The calculation requires courts to engage in a "what if" exercise: compare the situation that the anti-competitive conduct has created to a situation that would have existed absent such conduct. In some cases the court might be able to use benchmark prices and market conditions from an earlier period or from other, relatively similar, markets. Yet, when this is not possible, the court must engage in a theoretical comparison, which raises calculation challenges. They include, inter alia, the following examples.

First, courts must give weight to the effects of external changes in market conditions, which are not related to the anti-competitive conduct, on market conditions and conduct. Such changes might include, for example, the exit of a competitor for reasons unrelated to the infringement or a change in the prices of some inputs that affect all suppliers.

Second, courts may face difficulties in determining the extent of a new entry that was blocked by the anti-competitive conduct. The Israeli Elite/ Cadbury case illustrates this point. ${ }^{55}$ Cadbury, a producer of chocolates, tried to enter the Israeli market. Elite, which holds a monopoly position in the market for chocolate, engaged in clearly abusive conduct which erected artificial entry barriers: it set predatory prices and entered into agreements with some supermarkets that prohibited them from placing Cadbury chocolates near the register or from selling them at all. There was no doubt

\footnotetext{
${ }^{54} \mathrm{Gal}$, "Free movement".

${ }^{55}$ AT 612/06 Gen. Dir. v. Straus Elite Ltd. ATTRIB, 37(4) Dinim Mehozi 298, 2007 Antitrust 5000477.
} 
that this conduct fell squarely within the abuse of dominance prohibitions. Cadbury then sued for damages. It argued that its damages amounted to eighty million Israeli shekels; Elite argued for six. Since Cadbury chocolate was never sold in Israel, Elite claimed that it was not proven that consumers would have liked the taste, and it was uncertain whether Cadbury complied with some regulatory requirements. Such cases raise even more fundamental challenges: even if Cadbury had entered, a status quo might have been created in which Cadbury would have enjoyed the price umbrella ${ }^{56}$ formed by the monopolist and would have set its prices at monopolistic or near monopolistic levels. Theoretically, the loss of such monopolistic profits could serve as a basis for calculating the damages the potential entrant suffered, even if consumers were not harmed. The question arises whether the potential entrant should be compensated for its loss of ability to charge monopolistic prices. The final example of a calculation challenge relates to the ability to use the price in the market, once a cartel has ceased to operate, as a benchmark for the "what if" test. The reason is that market conditions may be "sticky" in the sense that market parties might be used to high prices and no longer need direct contact, but rather engage in oligopolistic coordination which achieves similar results to the cartel.

These expected difficulties in the calculation of damages can be reduced by several institutional and legal methods which should be developed or applied by courts. For example, courts must ensure that they have good economic consultants. Such consultants can be brought by the parties, nominated by the court, or even form part of the court hearing the case. In addition, it is advisable that decision-makers learn from the experience of other decision-makers who have confronted such issues in the past. U.S. courts, in particular, have gained much experience over the years in calculating competition law damages. It might be worthwhile for the Commission or for national competition authorities, once private actions become more commonplace, to take steps to ensure that EU courts need not start experimenting anew where established and efficient calculation methods exist elsewhere. This can be achieved through guidance papers, amici curiae, or seminars. While in some cases the parties to the case might have incentives to bring such information before the court, in others

${ }^{56}$ Such an effect arises when a cartel or monopoly affecting part of a relevant market causes prices in the rest of the market to rise. See Phillip E. Areeda and Herbert Hovenkamp, Antitrust Law: An Analysis of Antitrust Principles and Their Application, $2^{\text {nd }}$ Edition (The Hague: Wolters Kluwer Law \& Business, 2000): 347. 
they might be incentivised to strategically expose only those rules which serve their purposes or might not be aware of such rules, or the size of the damages might not justify an investment in studying foreign experience.

\section{Applying Divergent Procedural Rules?}

A final issue raised by private competition law enforcement is whether national courts hearing competition law cases should necessarily adopt similar procedural rules - such as burdens of proof and presumptions - to those adopted by the Commission, national competition law authorities, or European courts reviewing the decisions of the former. The question arises due to the diverse institutional features of the different decision-makers involved in competition law enforcement. Of particular importance is the divergence in the level of economic expertise and market analysis abilities of national courts compared to competition agencies, as well as the resources each has for engaging in an in-depth economic analysis.

The argument for procedural rules that reflect the different institutional capabilities of divergent decision-makers is based on decision theory. ${ }^{57}$ Decision theory is an analytical tool for shaping legal rules that takes into account conceptual considerations as well as the institutional features and practical abilities of decision-makers. It balances the legal process costs of obtaining and analysing all the relevant information, with the error costs resulting from impartial information or its erroneous analysis. The former include costs of gathering factual data and the costs of analysing it (including the employment of external experts, where necessary). The latter include false positives, which arise when the rule is applied too widely and captures conduct that does not harm social welfare, and false negatives, when the rule is applied too narrowly and does not capture those types of conduct that harm social welfare. The probability of error is affected, inter alia, by decision-makers' characteristics, especially their ability to analyse and understand the information before them. Accordingly, an optimal legal rule is not necessarily one that would lead to a hypothetically efficient

\footnotetext{
${ }^{57}$ See, e.g., Isaac Ehrlich and Richard A. Posner, "An economic analysis of legal rulemaking", Journal of Legal Studies 3, no. 1 (1974): 257. For the application of the decision theory in competition law see, e.g., Arndt Christiansen and Wolfgang Kerber, "Competition policy with optimally differentiated rules instead of 'per se rules vs rule of reason", Journal of Competition Law es Economics 2, no. 2 (2006): 215; C. Frederick $\otimes$ Beckner and Steven C. Salop, "Decision theory and antitrust rules", Antitrust Law Journal 67, no. 1 (1999): 41; Mark S. Popofsky, "Defining exclusionary conduct: Section 2, the rule of reason, and the unifying principle underlying antitrust rules", Antitrust Law Journal 73, no. 2 (2006): 435.
} 
outcome, but one that maximizes social welfare under realistic assumptions of enforcement, to ensure that its benefits outweigh its costs of application in practice.

In line with decision theory, the divergent institutional capabilities of national courts and competition agencies might justify different optimal procedural rules for the same anti-competitive conduct and the same legal provision. For example, where the decision-maker enjoys strong analytical capabilities, and therefore his error costs of analysing complex economic situations are low, a rule of reason might be justified, and vice versa. This, in turn, might justify the creation of stronger - even if less economically accurate - presumptions in cases heard by national courts, might affect the allocation of burdens of proof, and might justify placing stronger limitations on certain cases heard by national courts, such as excessive pricing cases.

At the same time, when deciding whether to apply similar rules, broader considerations should not be disregarded. Of particular importance is the ability of the European Court of First Instance and the European Court of Justice, as well as of the Commission, to provide guidance to national courts in applying competition law prohibitions. This is especially important at the current formative stage, where most national courts are just beginning to hear competition law cases. Applying similar rules also increases certainty and predictability for all parties involved. Such benefits are on-going: the continued application of similar rules by all decisionmakers generates positive network externalities: as more decisions that apply the law to various factual settings accumulate, legal certainty is typically further increased. It also saves the costs that national courts would have incurred in the course of determining what rules to apply and limit potential divergence across Member States. ${ }^{58}$

Accordingly, it is suggested that in general the procedural rules applied by national courts follow those of the European Courts, the Commission, and national competition agencies. Nonetheless, where institutional differences significantly affect error costs, divergent procedural rules should be contemplated. The Commission, national competition agencies, and EU Courts can assist in the shaping of such procedural rules to ensure harmonization across national courts.

\footnotetext{
${ }^{58}$ See, e.g., Michal Gal, "The 'cut and paste' of article 82 of the EC Treaty in Israel: Conditions for a successful transplant”, European Journal of Law Reform 9, no. 3 (2007): 467.
} 


\section{Conclusion}

Private enforcement is on the road to soon become an important new pathway for competition law enforcement. While it brings about significant benefits, it also raises concerns that its application in practice might not always be optimal and might even harm social welfare. The EU and Member States are currently in the formative period which will set the stage for private actions for years to come. It is thus important to invest in recognising and trying to avoid potential pitfalls, some of which plague existing private competition law enforcement elsewhere. Accordingly, this short article has attempted to shed light on several challenges that must be addressed in order to enable private competition law enforcement to bring about its potential benefits, suggesting some solutions that can be adopted to address such challenges. This article makes clear that the adoption of the Damages Directive is only the first step in the important process of shaping their application in order to increase social welfare.

\section{Bibliography}

Beckner, C. Frederick and Steven C. Salop. "Decision theory and antitrust rules". Antitrust Law Journal 67, no. 1 (1999): 41-76.

Brodley, Joseph F. “Antitrust standing in private merger cases: Reconciling private incentives and public enforcement goals". Michigan Law Review 94, no. 1 (1995): 1-109.

Butenko, Anna and Pierre Larouche. "Regulation for innovativeness or regulation of innovation?". Law, Innovation and Technology 7, no. 1 (2015): 52-58.

Choi, Albert H. and Kathryn Spier. "Class actions and private antitrust litigation". Virginia Law and Economics Research Paper 29, no. 1 (2019).

Christiansen, Arndt and Wolfgang Kerber. "Competition policy with optimally differentiated rules instead of 'per se rules vs rule of reason'”. Journal of Competition Law \& Economics 2, no. 2 (2006): 215-244.

Davis, Joshua, P. and Robert H. Lande. "Toward an empirical and theoretical assessment of private antitrust enforcement”. Seattle University Law Review 36, no. 3 (2013): 1269-1333.

Demsetz, Harold. The Economics of the Business Firms: Seven Critical Commentaries. Cambridge: Cambridge University Press, 1995.

Ehrlich, Isaac and Richard A Posner. "An economic analysis of legal rulemaking". Journal of Legal Studies 3, no. 1 (1974): 257-286.

European Commission (1975). Fifth Report on Competition Policy.

European Commission (1994). XXIV th Report of on Competition Policy. 
European Commission (1997). XXVII ${ }^{\text {th }}$ Report on Competition Policy.

Gal, Michal. "Abuse of dominance - exploitative abuses". In Handbook on European Competition Law, edited by Ioannis Lianos and Damien Geradin, 385-422. Cheltenham, UK; Northampton, MA, USA: Edgard Elgar, 2013.

Gal, Michal. "Free movement of judgments: Increasing deterrence of international cartels through jurisdictional reliance". Virginia Journal of International Law 51, no. 1 (2010): 57-94.

Gal, Michal. "The case for limiting private litigation of excessive pricing cases”, forthcoming. Journal of Competition Law and Economics (2020) (2019, on file with author).

Gal, Michal. "The 'cut and paste' of article 82 of the EC Treaty in Israel: Conditions for a successful transplant”. European Journal of Law Reform 9, no. 3 (2007): 467.

Gal, Michal and Alan D. Miller. "Patent challenge clauses: A new antitrust offense?". Iowa Law Review 102, no. 4 (2016): 1477-1532.

Gal, Michal and Inbal Faibish-Wassmer. "Six principles for limiting governmentfacilitated restraints on competition". Common Market Law Review 44, no. 1 (2007): 69-100.

Hordijk, Erik Pijnacker. "Excessive pricing under EC competition law: An update in light of Dutch developments". In International Antitrust Law and Policy, edited by Barry Hawk, 463-495. New York: Juris Publishing, 2001.

International Competition Network, Advocacy and Competition Policy - Report prepared by the Advocacy Working Group, i-iii, 2002.

Lande, Robert H. and Joshua P. Davis. "Comparative deterrence from private enforcement and criminal enforcement of the U.S. antitrust laws". Brigham Young University Law Review, no. 2 (2011): 315-387.

Lande, Robert H. and Joshua P. Davis. "Restoring the legitimacy of private antitrust enforcement". In A Report to the $45^{\text {th }}$ President of the United States (American Antitrust Institute's Transition Report on Competition Policy), 219.

McAfee, R. Preston, Hugo M. Mialon, and Sue H. Mialon. "Private v. public antitrust enforcement: A strategic analysis”. Journal of Public Economics 92, no. 10-11 (2008): 1863-1875.

Miller, Alan D. and Michal Gal. "Licensee patent challenges”. Yale Journal on Regulation 32, no. 1 (2015): 121-151.

OECD, Relationship between Regulators and Competition Authorities (1999).

OECD, Roundtable on Excessive Pricing, DAF/COMP 2011 (2011).

Popofsky, Mark S. "Defining exclusionary conduct”. Antitrust Law Journal 73 (2006): 435-482.

Popofsky, Mark S. "Section 2, Safe harbors, and the rule of reason". George Mason Law Review 15, no. 5 (2008): 1265-1296. 
Schinkel, Maarten Pieter and Jakob Rüggeberg. "Consolidating antitrust damages in Europe: A proposal for standing in line with efficient private enforcement”. World Competition 29, no. 3 (2006): 395-420.

Spiegel, Yossi. "Antitrust enforcement of the prohibition of excessive pricing - the Israeli experience". In Excessive Prices and Competition Law Enforcement, edited by Frédéric Jenny F and Yannis Katsoulacos, 127-158. Cham: Springer International Publishing, 2018.

Waller, Spencer Weber. “Towards a constructive public-private partnership to enforce competition law". World Competition 29, no. 3 (2006): 367-381.

Wils, Wouter P.J. “The relationship between public antitrust enforcement and private actions for damages". World Competition 32 (2009): 3-26. 